\title{
New HCCl/CAI Combustion Process Development: Methodology for Determination of Relevant Fuel Parameters*
}

\author{
N. Jeuland ${ }^{1}, X$. Montagne $^{1}$ and P. Duret ${ }^{1}$ \\ 1 Institut français du pétrole, 1 et 4, avenue de Bois-Préau, 92852 Rueil-Malmaison Cedex - France \\ e-mail: nicolas.jeuland@ifp.fr - xavier.montagne@ifp.fr - pierre.duret@ifp.fr
}

* From the conference proceedings "Which Fuels For Low- $\mathrm{CO}_{2}$ Engines?" published in full by Éditions Technip

\begin{abstract}
Résumé - Développement des nouveaux procédés de combustion CAI/HCCI : méthodologie de détermination des propriétés critiques du carburant - Afin de satisfaire les impératifs simultanés de diminution des niveaux de pollution et des émissions de $\mathrm{CO}_{2}$, qui sont les deux principaux défis des motorisations futures, de nombreux travaux de recherche sont actuellement menés de par le monde sur de nouveaux modes de combustion, tels que l'auto-inflammation contrôlée $\left(\mathrm{CAI}^{\mathrm{TM}}\right)$ pour les moteurs à essence, et combustion homogène de type HCCI (homogeneous charge compression ignition) pour les moteurs Diesel. Ces nouveaux procédés permettent de réduire d'un facteur 10 à 100 les émissions de particules et de NOx par rapport aux moteurs à essence ou Diesel standard. Le problème principal dans le développement de tels modes de combustion reste la gamme restreinte de régime et de charge compatible avec un fonctionnement correct du moteur, aux niveaux acceptables d'émissions de NOx (Nitric Oxide emissions) et de bruit. Une des voies prometteuses permettant d'étendre la gamme de fonctionnement de la combustion CAI est la recherche de formules de carburants mieux adaptées, optimisées par la modification et le contrôle de leurs propriétés d'auto-inflammation et/ou leurs propriétés physiques et chimiques afin d'améliorer le démarrage et le déroulement de la combustion.

Dans cet article, nous présentons une nouvelle procédure de sélection de carburants, offrant une meilleure caractérisation de limpact du carburant sur le fonctionnement en $\mathrm{CAI}^{\mathrm{TM}}$, selon diverses conditions de régime de moteur et de charge. L'utilisation de cette méthodologie pour une large gamme de carburants, formulés en fonction de leurs propriétés d'auto-inflammation, de volatilité et de composition chimique, souligne la complexité de l'influence du carburant et permet d'identifier les caractéristiques du carburant ayant une influence notable sur le fonctionnement du moteur et l'élargissement de la zone de fonctionnement CAI.
\end{abstract}

Abstract - New HCCI/CAI Combustion Process Development: Methodology for Determination of Relevant Fuel Parameters - To pass the simultaneous emission requirements for near zero pollutant and low $\mathrm{CO}_{2}$ levels, which are the challenges for future powertrains, many research studies are currently carried out over the world on new engine combustion processes, such as controlled auto-ignition $\left(C A I^{T M}\right)$ for gasoline engines and homogeneous charge compression ignition (HCCI) for Diesel engines. These new processes have the potential to reduce, by a factor of 10 to 100, NOx (Nitric Oxide emissions) and particulate (PM) emissions in comparison with a typical gasoline or diesel engine. The main issue in the development of such combustion modes remains the limited range of engine speed and load that enable correct engine running, with acceptable levels of NOx and noise emissions. One of the promising 
ways to increase the CAI combustion range lies in the research of more adapted fuels, optimized to enhance combustion initiation by modifying and controlling their auto-ignition characteristics and/or their physical and chemical properties.

A new procedure is set-up to select fuels, which allows a better characterization of the fuel impact on engine running in CAI, for various conditions of speed and load. The use of this methodology with a wide range of fuels, formulated according to their auto-ignition characteristics, volatility and chemical composition, underlines the complexity of the action of fuel and points out the most influent fuel characteristics for a wide range of running conditions.

\section{INTRODUCTION}

Fuels and engines used in road transportation have to face two main challenges in a highly competitive economy:

- To reduce pollutant emission levels to values such that air quality in the cities complies with world health organization standards.

- To reduce the emissions of carbon dioxide $\left(\mathrm{CO}_{2}\right)$, regarded as the major greenhouse gas ( $\mathrm{GHG}$ ) contributing to global warming and climate changes.

The stochiometric gasoline four stroke engine with a 3-way catalyst has the ability to reach ultra-low emission levels for passenger cars such and to pass the Euro IV and even the future Euro V requirements. On the other hand, its efficiency remains moderate when compared to Diesel engines. Different strategies to improve its efficiency were recently considered.

- Direct fuel injection (DI) technology could be adopted, with stratified charge and lean burn combustion systems over a limited operating range. This lowers fuel consumption through reduced pumping and reduced heat transfer losses, but a major challenge is to reach ultra-low pollutant emission levels because of the need for a sophisticated and fuel sensitive DeNOx after-treatment device.

- Another approach would be to keep the conventional stochiometric 3-way catalyst engine for its low emission levels and to reduce fuel consumption by using new technologies such as variable valve actuation, down-sizing with supercharging, etc.

Beside these two approaches, there is a strong industrial need for an alternative highly efficient lean burn combustion system, which could provide $\mathrm{CO}_{2}$ advantages similar to stratified Diesel engines while solving the NOx emission problem of lean burn combustion, without depending on fuel sensitive and expensive after-treatment systems.

To meet these challenges, many studies are currently being carried out, especially on new combustion processes such as controlled auto-ignition $\left(\mathrm{CAI}^{\mathrm{TM}}\right)$ for gasoline engines and homogeneous charge compression ignition (HCCI) for Diesel engines. These new processes offer the potential to strongly reduce nitric oxide emissions (NOx) and particulate emissions (PM) in comparison with a typical gasoline or Diesel engine.

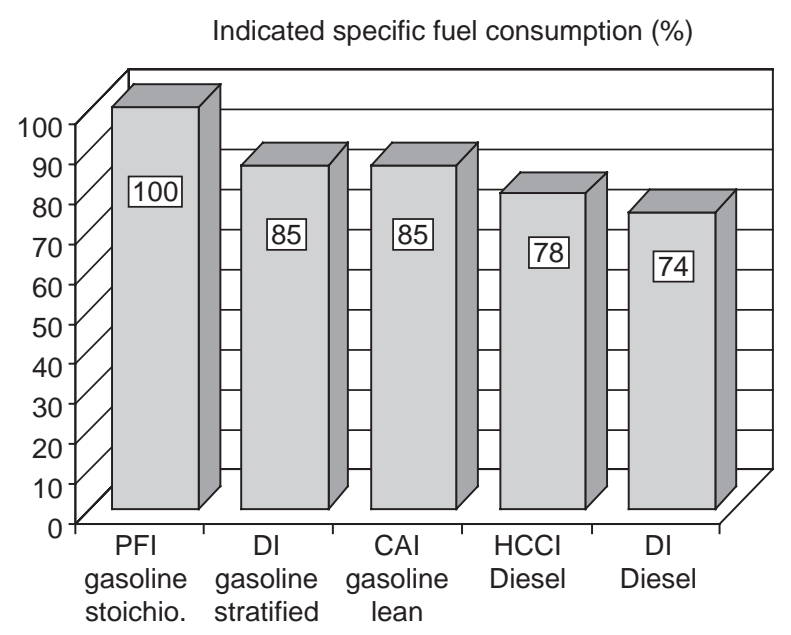

Figure 1

Compared fuel consumption between various gasoline and Diesel engine combustion processes (1500 rpm - 3 bar IMEP).

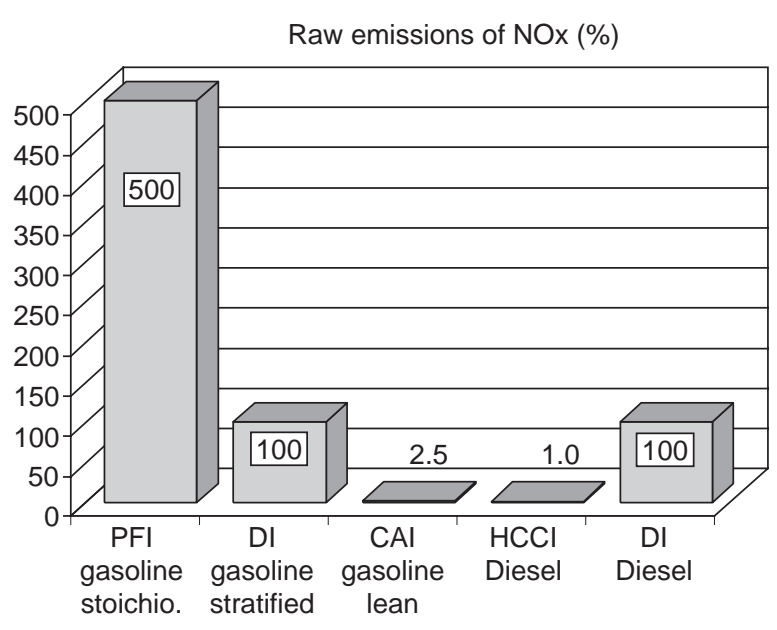

Figure 2

Compared NOx emissions between various gasoline and Diesel engine combustion processes (1500 rpm - 3 bar IMEP). 
Their principle consists in preparing a highly diluted mixture of air, fuel and residual gases, in achieving its simultaneous ignition in the whole space of the combustion chamber and in closely controlling the combustion event for best performance in terms of efficiency and NOx/PM emissions (timing and heat release rate during the cycle). Thanks to the thermo-chemistry of the charge, thermal NOx formation and soot production are in principle much lower than in the diffusion flame typical of the conventional diesel or in the propagation flame typical of the conventional spark ignition engine. Figures 1 and 2 show an example of very the promising results that can be obtained [1-3].

For the gasoline engine application, the generic term of HCCI is sometimes also used. The reason why the terms "gasoline controlled auto-ignition" (or gasoline CAI) are here preferred to "gasoline homogeneous charge compression ignition" is that in the approach described here, it is possible to auto-ignite the fresh charge in a 4-stroke gasoline engine without the need for intake air heating or increased compression ratio. This means that the same engine is also able, without engine design modification, to move from gasoline CAI at partial load to SI (spark ignition) at full load for maintained performance. Based on 15 years of 2-stroke CAI combustion background, the scientific methodology used was to transfer the 2-stroke combustion process to the 4-stroke engine, trying to reproduce the same in-cylinder conditions during the compression stroke. The first results of this innovative approach, based on the use of a high quantity of stratified internal EGR in a 4-stroke engine, as can be achieved in 2-stroke engines [4-7], were published and fully detailed in previous papers [8-10]. This "negative valve overlap" approach [11] enables, probably for the first time, to successfully run a 4-stroke engine in gasoline controlled auto-ignition. As this gasoline CAI is not homogeneous, the "H" letter of "HCCl" appears to be inappropriate. This is the reason why the name "gasoline CAI" is much preferred to "gasoline HCCI" [12].

\section{DEVELOPMENT OF A FUEL CHARACTERIZATION METHODOLOGY}

One of the key issues with the CAI combustion process, based on the use of a high rate of internal EGR, is the close control of the switch from the CAI mode to the classical SI mode. This is needed both at very low load (for combustion stability reasons) and at high load (to avoid knock). To address this concern, several manufacturers developed variable valve trains able to change valve timing from cycle-tocycle $[13,14]$. These systems could help to get more flexible cycle-to-cycle combustion control and to extend the CAI application range, which is the other key issue of the concept. But for the time being, the devices remain rather complex, expensive and they induce a significant increase in the number of engine parameters to control.
Another parameter which could significantly affect the performance of new CAI and HCCI combustion processes is the fuel composition, as shown by [15]. The use of specific fuels or additives could be an interesting solution to increase the benefits of the CAI combustion process, by extending its application range [16-18]. The IFP background and knowhow already pointed out this significant influence of fuel composition and physical properties on CAI combustion (especially in terms of operating range, pollutant emissions and noise, etc.). In previous work on 2-stroke CAI engines, IFP showed that the benefits of such new combustion processes could be greatly enhanced with more appropriate fuel (and/or additives) formulations, which have to be studied and developed. Before starting such studies, it was necessary to define a test procedure enabling the evaluation of the fuel effect on the CAI.

\subsection{Method Description}

\subsubsection{Basic Principle}

Since the method has already been described in previous publications $[19,20]$ then, only the most important points are summarized here.

The method is based on an index, called "CAI Number" or CAN. This index was initially developed for 2-strokes engines [9] and it was then adapted to 4-strokes engines [19]. Its principle can be summarized as follows:

- definition of engine running limitations (intake air pressure, combustion noise, NOx emissions, engine stability);

- evaluation of the CAI running zone for each fuel with these parameters;

- comparison of this CAI running zone with the one measured for a reference fuel.

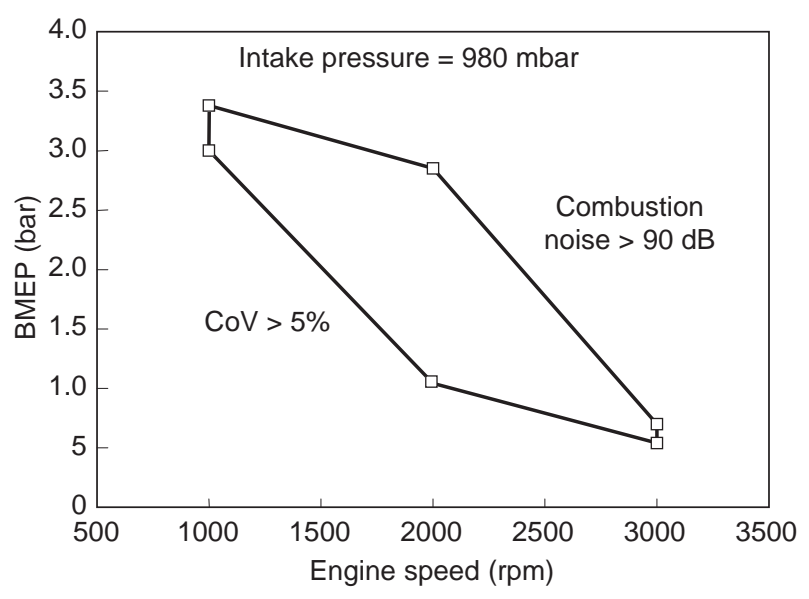

Figure 3

CAI running zone definition. 
The running zone defined by this method is illustrated in figure 3.

The CAI running zone is limited at low speed/low load by the engine stability: when the temperature is too low to ensure a correct auto-ignition of the air/fuel mix, the IMEP becomes highly unstable (misfiring). It is also limited at high load, when several cumulative phenomena tend to limit its operating range. The combustion noise can reach the $90 \mathrm{~dB}$ limitation and in some cases, the maximum acceptable NOx level can be reached. Another high load limiting factor could be, with some special "low noise/low NOx/CAI" fuels, the air flow intake itself. As explained before, when the maximum intake pressure is reached, the maximum volumetric efficiency becomes limited by the "negative valve overlap" configuration used in this study to obtain CAI part load operation. Therefore, it must be pointed out that in the following results, the two first criteria (noise and NOx) are truly dependant on the fuel effect while the third (limited volumetric efficiency) could sometimes (with fuels adapted for high load CAI) limit the level of maximum load in CAI, independently of the fuel effect.

This method, tested with various fuel types, appeared to be able to discriminate between fuels according to their impact on the CAI running zone. Nevertheless, this method also appeared to be too global to enable a correct interpretation of the combustion phenomena. Indeed, 2 fuels can have a similar index and still have radically different behaviors, as shown in Figure 4.

In this example, the 2 best fuels have a radically different behavior, despite a similar CAN index: fuel 1 tends to enhance CAI combustion at low speed/low load, while fuel 2 tends to increase the CAI combustion in both low load and high load conditions. Consequently, a unique calculated value does not seem to be sufficient to fully describe all the fuel behaviors observed with 4-stroke CAI running conditions and has to be completed with additional information.

\subsubsection{Modification of the Characterization Procedure}

A comprehensive index, providing information on the fuel effect on the whole CAI running zone, has to describe the behavior at all speed and load running conditions. For this, the CAN index for CAI 4-stroke engines was divided into 4 parts to describe the effect of fuel on the 4 types of running conditions (Fig. 5):

- low speed/low load (zone 1);

- low speed/high load (zone 2);

- high speed/high load (zone 3);

- high speed/low load (zone 4).

For each zone, one indicator can be determined. To calculate them, the CAI range obtained with a reference fuel (Fig. 6, area 1, 2, 3, 4, 5, 6) was divided into 4 zones, defined according to the mean value of minimum and maximum BMEP obtained for each engine speed.

$$
\begin{aligned}
& -1000 \mathrm{rpm}\left(\text { point } \mathrm{A}=\frac{(1)+(2)}{2}\right) \\
& -2000 \mathrm{rpm}\left(\text { point } \mathrm{B}=\frac{(3)+(6)}{2}\right) \\
& -3000 \mathrm{rpm}\left(\operatorname{point} \mathrm{C}=\frac{(4)+(5)}{2}\right)
\end{aligned}
$$

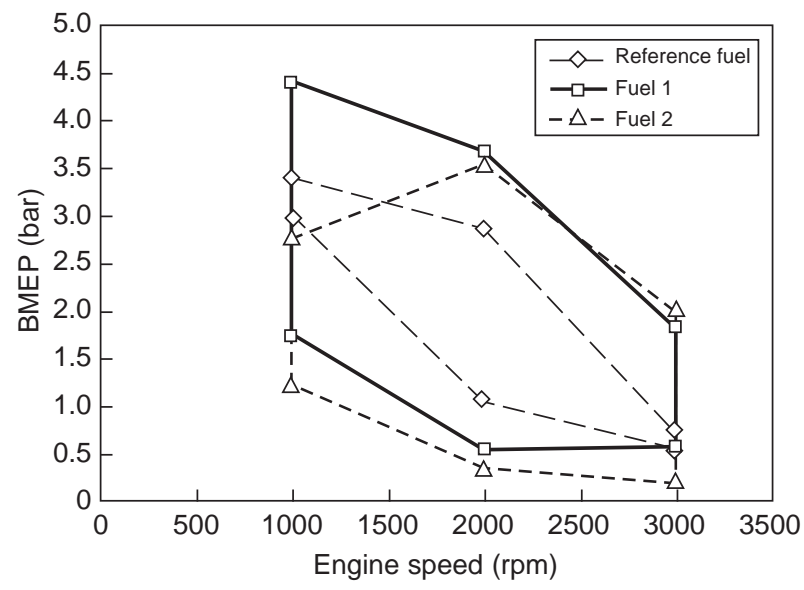

Figure 4

Comparison of fuel effect on CAI running zone.

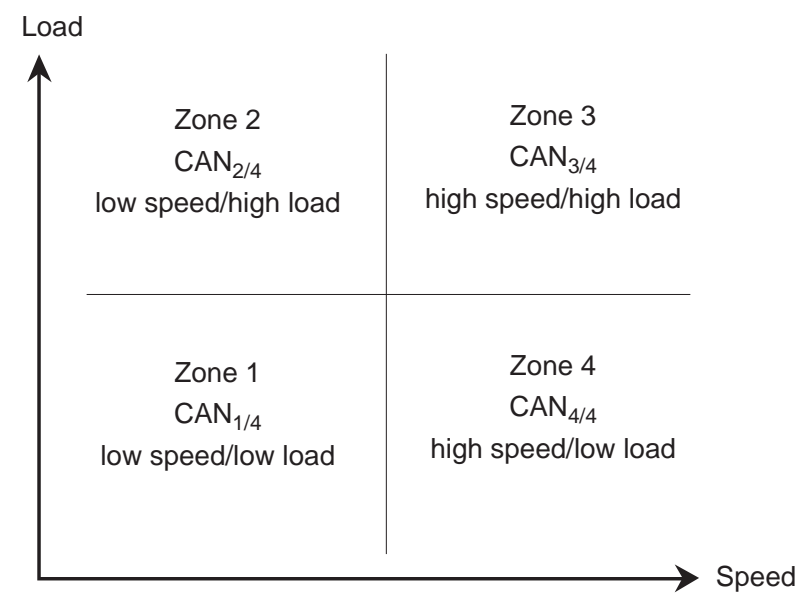

Figure 5

Speed/load field division in 4 zones. 


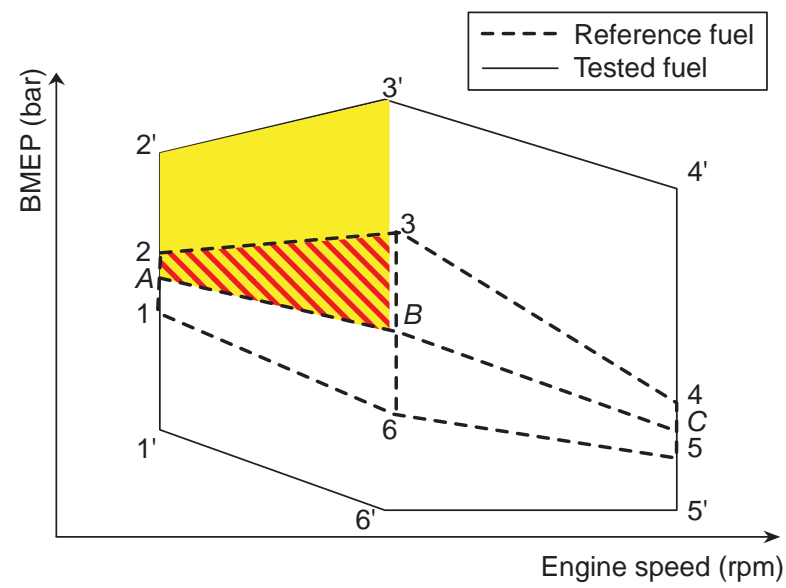

Figure 6

Principle of CANs calculation.

The 4 CANs are then calculated according to the following formulas:

$$
\begin{aligned}
& \mathrm{CAN}_{2 / 4}=\frac{\operatorname{area}\left(A-2^{\prime}-3^{\prime}-B\right)}{\operatorname{area}(A-2-3-B)} \\
& \mathrm{CAN}_{1 / 4}=\frac{\operatorname{area}\left(A-1^{\prime}-6^{\prime}-B\right)}{\operatorname{area}(A-1-6-B)} \\
& \mathrm{CAN}_{3 / 4}=\frac{\operatorname{area}\left(B-3^{\prime}-4^{\prime}-C\right)}{\operatorname{area}(B-3-4-C)} \\
& \mathrm{CAN}_{4 / 4}=\frac{\operatorname{area}\left(B-6^{\prime}-5^{\prime}-C\right)}{\operatorname{area}(B-6-5-C)}
\end{aligned}
$$

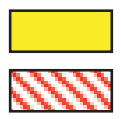

This method is more complicated than the first characterization method, but it enables much more accurate analyses of the phenomena linked to CAI combustion.

\section{IDENTIFICATION OF RELEVANT FUEL PARAMETERS FOR CAI RUNNING}

The method described above has been applied on a set of fuels to obtain information on the most influential fuel parameters.

\subsection{Description of the Fuel Matrix}

The tested fuels were divided in groups, according to their main characteristics (Tables 1 and 2).

\section{TABLE 1}

Tested fuels composition

\begin{tabular}{c|l}
\hline "REF" & $\begin{array}{l}\text { Reference EN228 gasoline fuel } \\
\text { (RON 97; MON 86) }\end{array}$ \\
\hline "REF+ ${ }_{1} "$ & $\begin{array}{l}\text { Blend of reference fuel with } 0.2 \% \mathrm{NEH} \\
\text { (nitrate ethyl hexyl, a commonly used } \\
\text { procetane additive) }\end{array}$
\end{tabular}<smiles>CCCCC(CC)CO[N+](=O)[O-]</smiles>

"REF $+_{2} " \quad$ Blend of reference fuel with $0.2 \%$

\begin{tabular}{|c|c|}
\hline "DLF1" & Low sulfur Diesel fuel (50 ppm) \\
\hline "DLF2" & Euro III Diesel fuel (350 ppm sulfur) \\
\hline "DLF3" & $n$-heptane \\
\hline "DLF4" & $\begin{array}{l}\text { Wide cut kerosene, called Jet B or NATO F } 45 \text {, } \\
\text { characterized by its high volatility (initial boiling } \\
\text { point around } 80^{\circ} \mathrm{C} \text { ) and an intermediate cetane } \\
\text { index (35) }\end{array}$ \\
\hline "DLF5" & $\begin{array}{l}\text { Fischer-Tropsch fuel, characterized by a very high } \\
\text { cetane number }\end{array}$ \\
\hline "GLF" & $\begin{array}{l}\text { Blend of fuels DLF4 (Jet B) and REF (gasoline } \\
\text { fuel), } 50 \% \text { each }\end{array}$ \\
\hline "GLF2" & $\begin{array}{l}\text { Blend of fuels REF (EN } 228 \text { gasoline) and } \\
\text { DLF2 (EN590 Diesel fuel) }\end{array}$ \\
\hline "O1" & Ethanol \\
\hline "O2" & Blend of ethanol and ethylal (50\%vol each) \\
\hline "O3" & $\begin{array}{l}\text { Blend of methanol and methylal ( } 50 \% \text { each). } \\
\text { This fuel was included in the fuel matrix but could } \\
\text { not be tested, due to an engine failure }\end{array}$ \\
\hline "BO" & $\begin{array}{l}\text { Blend of fuels DLF4 (Jet B) and O3 (methanol/ } \\
\text { methylal) }\end{array}$ \\
\hline
\end{tabular}

of ditert-butyl peroxide, another commercial procetane additive

$$
\mathrm{H}_{3} \mathrm{C}-\left.\left.\right|_{\mathrm{CH}_{3}} ^{\mathrm{CH}_{3}}{ }_{\mathrm{OC}}\right|_{\mathrm{CH}_{3}} ^{\mathrm{CH}_{3}} \mathrm{H}_{3}
$$

$*$ : calculated values 
TABLE 2

Main test fuels characteristics

\begin{tabular}{c|c|c|c|c|c}
\hline & RON $^{*}$ & $\begin{array}{c}\text { Cetane } \\
\text { number }^{*}\end{array}$ & $\begin{array}{c}\text { Density } \\
(\mathrm{g} / \mathrm{l})\end{array}$ & $\begin{array}{c}\mathrm{IBP} \\
\left({ }^{\circ} \mathrm{C}\right)\end{array}$ & $\begin{array}{c}\mathrm{FBP} \\
\left({ }^{\circ} \mathrm{C}\right)\end{array}$ \\
\hline $\mathrm{REF}_{+1}$ & $70-80$ & $<0$ & 740 & $<50$ & $150-200$ \\
$\mathrm{REF}_{+2}$ & $70-80$ & $<0$ & 740 & $<50$ & $150-200$ \\
$\mathrm{DLF}$ & $<0$ & 50 & 840 & $>200$ & $>300$ \\
$\mathrm{DLF} 2$ & $<0$ & 50 & 830 & $>200$ & $>300$ \\
$\mathrm{DLF} 3$ & 0 & 56 & 680 & $50-100$ & $100-150$ \\
$\mathrm{DLF} 4$ & $<0$ & 35 & 810 & $<50$ & $200-250$ \\
$\mathrm{DLF5}$ & $<0$ & 93 & 760 & $150-200$ & $>300$ \\
$\mathrm{GLF}$ & $<50$ & 10 & 770 & $<50$ & $200-250$ \\
$\mathrm{GLF} 2$ & $30-40$ & 40 & 780 & $<50$ & $>300$ \\
$\mathrm{O} 1$ & $50-60$ & - & 820 & $50-100$ & $50-100$ \\
$\mathrm{O} 2$ & $>100$ & - & 790 & $50-100$ & $50-100$ \\
\hline
\end{tabular}

\subsection{Impact of Fuel Parameters on CAI Running}

\subsubsection{Cetane Index}

The Figure 7 shows the impact of the cetane number on $\mathrm{CAN}_{1 / 4}$ and $\mathrm{CAN}_{2 / 4}$ (low speed running points).

This figure shows that the impact of the cetane index is strongly different when considered at low load, (zone 1: increase in CAI range when the cetane index increases) or at high load (zone 2: decrease in CAI range when the cetane index increases).

- At low load, the engine temperature is low, and the main issue for CAI combustion is the start of the combustion. If the cetane index is high, the fuel auto-ignition is facilitated, even if the temperature remains low, and the engine stability is enhanced, inducing a wider CAI combustion zone.
- At high load, on the contrary, the CAI zone is limited by the noise level, which is linked to the start of the combustion. If the fuel cetane index is high, combustion begins earlier in the cycle, the heat release rate rises and noise increases.

This figure also shows that other physical parameters have to be considered. For instance, DLF 5 (Fischer-Tropsch fuel), with a very high cetane index, should be the most efficient in enlarging the zone 1 (low load, low speed). This analysis shows that, on the contrary, this fuel is linked with one of the smallest $\mathrm{CAI}_{1 / 4}$.

\subsubsection{Density}

As the engine used for this study was a direct injection gasoline engine, the density of the fuel could have an influence on the combustion, via processes such as air/fuel mixture quality.

On first impressions, no clear link appears between fuel density and $\mathrm{CAN}_{2 / 4}$. Nevertheless, it can be observed that the Diesel-like fuels have an atypical behavior: while with other fuels, the CAI zone is linked to the density (higher density means wider CAI combustion zone), for Diesel-like fuels, no clear link is observed (Fig. 8).

In zone 3 (high speed, high load), this behavior is unchanged, as shown in the Figure 9.

This analysis shows that:

- for low cetane fuels, a higher density tends to increase the CAI combustion zone;

- for high cetane fuels, the density is a parameter of secondary importance.

\subsubsection{Latent Heat of Vaporization}

The latent heat of vaporization (LHV) is the energy needed to vaporize $1 \mathrm{~kg}$ of the product. A molecule with a high LHV

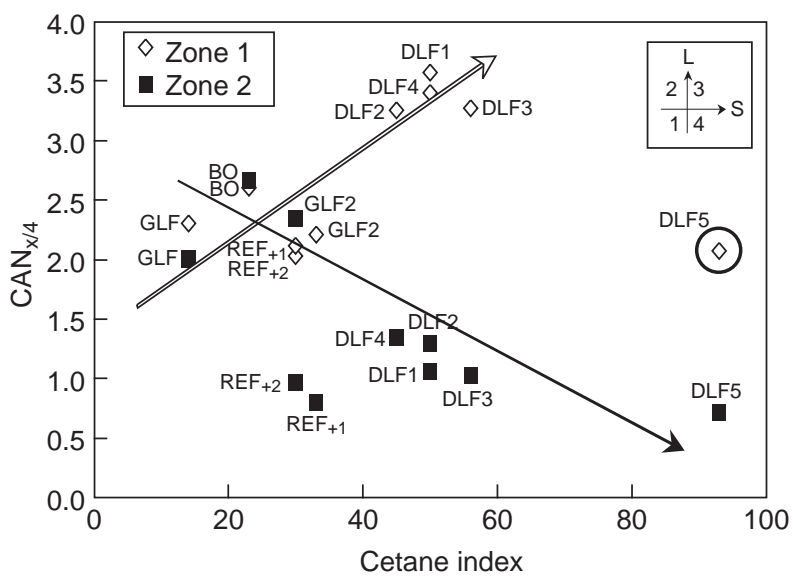

Figure 7

Impact of fuel cetane index on CAI running zone.

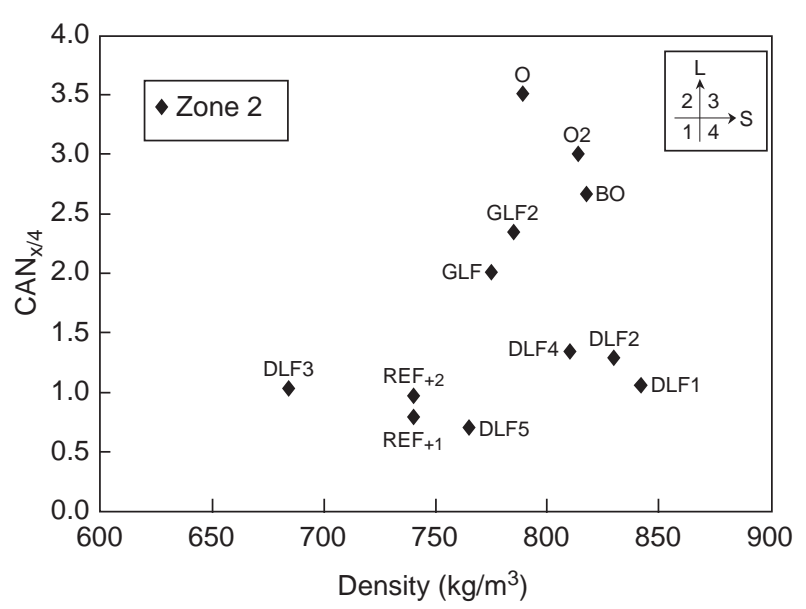

Figure 8

Correlation $\mathrm{CAN}_{2 / 4}$-density of the fuel. 


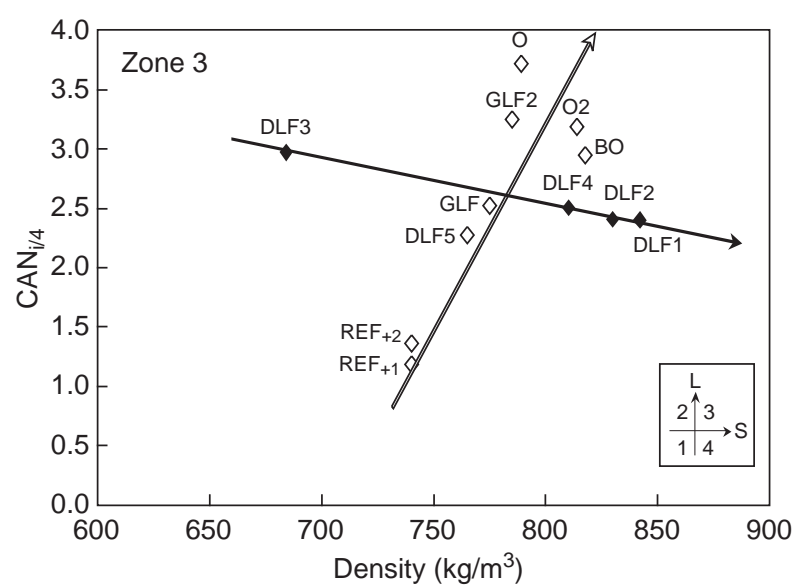

Figure 9

Correlation $\mathrm{CAN}_{3 / 4}$-density of the fuel.

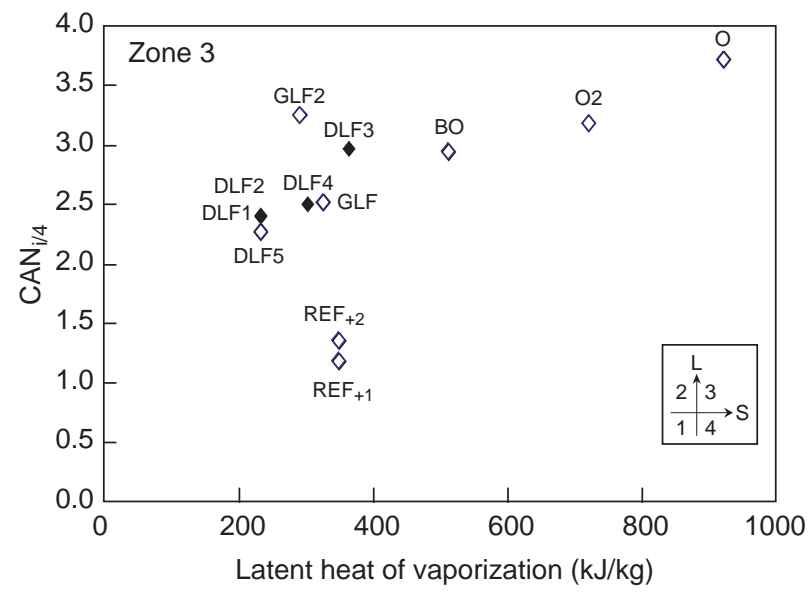

Figure 11

Correlation between LHV and $\mathrm{CAN}_{3 / 4}$.

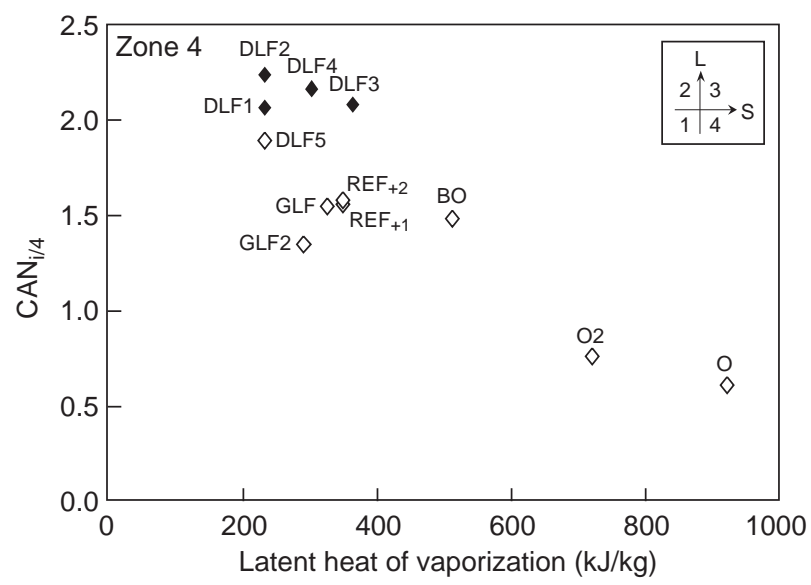

Figure 10

Correlation between LHV and $\mathrm{CAN}_{4 / 4}$.

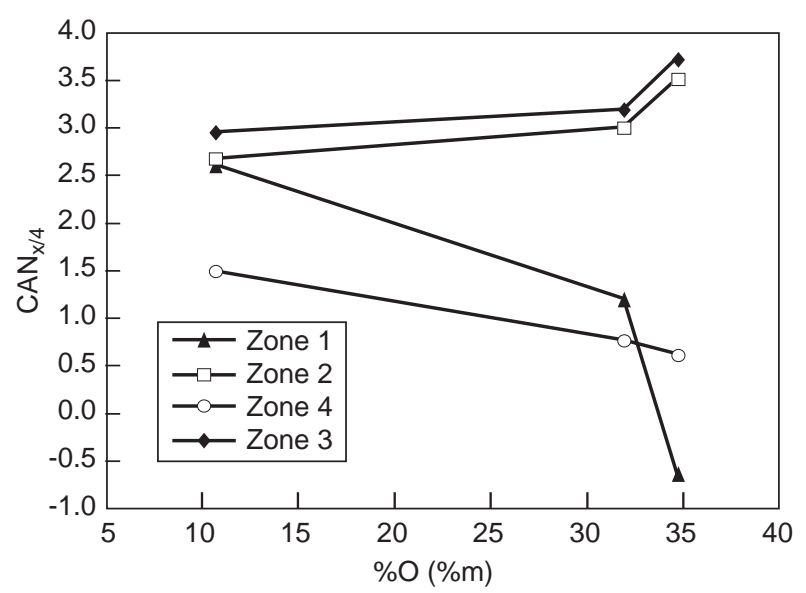

Figure 12

Correlation between fuel oxygen content and $\mathrm{CAN}_{\mathrm{x} / 4}$. traps an important quantity of energy during its vaporization, and thus decreases the temperature of the air/fuel mixture.

This parameter is strongly linked to the oxygen content of the molecule as oxygen induces the formation of intermolecular H-bonds (Van der Waals bonds), and consequently an important increase of the LHV. As a consequence, all the fuels have close LHV values, except oxygenated fuels.

The impact of this parameter on CAI running is linked to the running point (low or high load), as shown in Figures 10 and 11.

The impact of this parameter on the CAI zone is different according to the running point.

- At low load (zone 4), an increase in LHV decreases the CAI zone. Indeed, the cooling effect induces a decrease in cylinder temperature and, as a consequence, some ignition difficulties.
- At high load (zone 3), on the contrary, the cooling effect tends to dampen the combustion and consequently to enlarge the CAI zone.

\subsubsection{Oxygen Content}

Three fuels from the matrix contained oxygenated compounds: "O" (pure ethanol), "O2” (blend ethanol/ethylal) and "BO" (blend Jet B/methanol/methylal).

Figure 12 focuses on the results obtained for these fuels.

This figure shows that the impact of the oxygen content is dependant on the engine load.

- At low load (zones 1 and 4), an increase in the oxygen content leads to a narrowing of the CAI running zone.

- At high load, on the contrary, an increase in the fuel oxygen content leads to an enlargement of the CAI running zone. 
The analysis of zone 1 shows a specific behavior: ethanol (O) induces a negative CAN. The blend with ethylal (O2) induces a strong increase in the CAN. These evolutions are not due to LHV, but more to the cetane number increase induced by ethylal.

\section{DISCUSSION}

All the correlations that have been calculated can be brought together in a table to give a global view of the most influencing fuel parameters. In Table 3 below, a positive correlation is noted "+" and a negative correlation "--".

TABLE 3

Correlations between $\mathrm{CAN}_{\mathrm{x} / 4}$ and fuel parameters

\begin{tabular}{l|c|c|c|c|c|c|c}
\hline & RON & MON & IC & $\begin{array}{c}\text { Density } \\
\mathrm{kg} / \mathrm{m}^{3}\end{array}$ & $\begin{array}{c}\text { Heating } \\
\text { value } \\
\mathrm{kJ} / \mathrm{kg}\end{array}$ & $\begin{array}{c}\mathrm{IBP} \\
\left({ }^{\circ} \mathrm{C}\right)\end{array}$ & $\begin{array}{c}\mathrm{FBP} \\
\left({ }^{\circ} \mathrm{C}\right)\end{array}$ \\
\hline Zone 1 & - & & + & & + & + & \\
Zone 2 & & & - & $*$ & - & - & \\
Zone 3 & & & & $*$ & & & \\
Zone 4 & - & & + & & + & + & \\
\hline
\end{tabular}

* : dependant on fuel cetane number

\begin{tabular}{l|c|c|c|c|c|c|c}
\hline & $\% \mathrm{C}$ & $\% \mathrm{H}$ & $\% \mathrm{O}$ & $\mathrm{LHV}$ & $\mathrm{FBP}-\mathrm{IBP}$ & $\mathrm{E} \mathrm{50}$ & $\mathrm{E} \mathrm{100}$ \\
\hline & $\% \mathrm{~m}$ & $\% \mathrm{~m}$ & $\% \mathrm{~m}$ & $\mathrm{~kJ} / \mathrm{kg}$ & ${ }^{\circ} \mathrm{C}$ & $\%$ vol. & $\%$ vol. \\
\hline Zone 1 & + & + & - & - & & & \\
Zone 2 & - & - & + & + & & & \\
Zone 3 & - & & + & & & - & \\
Zone 4 & + & + & - & - & & & - \\
\hline
\end{tabular}

According to these results, it can be determined that an enlargement of the CAI zone at low speed/low load (zone 1) can be obtained through:

- an increase in fuel cetane;

- a low oxygen content;

- a low latent heat of vaporization.

On the opposite, in zone 2 (low load, high speed), to be efficient a fuel should have:

- a high oxygen content;

- a high latent heat of vaporization;

- a low cetane index.

As a consequence, the optimal fuel has to be a compromise between all these parameters.

Moreover, the results obtained here are only preliminary ones and deserve closer analysis. A set of fuels has been tested and some correlations have been calculated, without attemping any formulation optimization or trying to decorrelate the fuel properties.
So far, it remains difficult to identify precisely which fuel parameter is a truly important one. For instance, fuel volatility is positively correlated with initial boiling point and the CAI range for zones 1 and 4, which means that the optimal fuel at low load condition appears to be a heavy fuel. This observation is quite surprising, as the main issue at low load is to obtain satisfactory auto-ignition. It would have been more logical if heavy fuels, with their high initial boiling points and low volatility, would not rank as the best ones. In fact, these surprising results seem to be mostly due to the auto-ignition properties, as most of our fuels with high initial boiling points were "Diesel-like" fuels (Diesel fuel, FischerTropsch, etc.) with high cetane numbers, while, on the opposite, most of the fuels with low initial boiling points were "gasoline like" fuels (ethanol, gasoline, etc.) with low cetane numbers.

To obtain a more comprehensive evaluation of fuel impact on CAI running zone, the ability to discriminate between the fuels properties will be an unavoidable need. It should be considered early, when determining design of experimental method for instance, in order to be able to determine which parameter has the most influence in each zone: auto-ignition delay, volatility, density, chemistry of the fuel, combustion speed, etc.

\section{CONCLUSION}

The IFP-developed CAI ${ }^{\mathrm{TM}}$ combustion system has been applied to a conventional gasoline automotive 4-stroke engine. This engine has been used to undertake a detailed study of the influence of the fuel formulation on the engine operating range that can be covered in CAI combustion mode. From the information and results generated by this study, the following main conclusions can be stated:

- A repeatable and discriminating testing procedure was developed, able to show the fuel effect on the CAI running zone.

- The development of this method leads to the definition of four indices, according to the engine speed and load. The fuel impact has to be studied separately for each zone.

- The study of several fuel formulations has shown that the fuel selective formulation could be one of the relevant ways to strongly enlarge the CAI running zone in some of the four areas previously defined.

- Correlation calculations were achieved to try to link the fuel physical properties and the CAI running zone. It has been shown that the engine load is one of the main parameters modifying the fuel impact: at low load, fuel requirements would be a short auto-ignition delay and a low LHV, while at high load a longer auto-ignition delay and a high LHV would be preferred. A compromise between theses characteristics will be needed to determine the optimal fuel. 
- Further work is necessary to determine the true impact of each of the fuel physical parameters, and to be able to rank their influence on the CAI running area: auto-ignition delay, volatility, chemical composition, etc.

\section{ACKNOWLEDGEMENTS}

The authors would like to acknowledge Christophe Gunkel who performed all the engine tests.

\section{REFERENCES}

1 Douaud, A. (2001) Vers des technologies de combustion "ZÉRO" émissions, EET Paris, 20-21 Novembre.

2 Duret, P. and Douaud, A. (2001) New Combustion Processes: Homogeneous Diesel and Auto-Ignition Gasoline towards Zero Emission with Major Engine and Fuel Technology Challenges. Global Powertrain Congress, Detroit June 5-7.

3 Editions Technip (2001) A New Generation of Engine Combustion Processes for the Future. IFP International Congress, November 26-27.

4 Duret, P. and Venturi (1996) S. Automotive Calibration of the IAPAC Fluid Dynamically Controlled Two-Stroke Combustion Process. SAE 960363.

5 Ishibashi, Y. and Asai (1996) M. Improving the Exhaust Emissions of Two-Stroke Engine by Applying the Activated Radical Combustion. SAE 960742.

6 Duret, P., Dabadie, J.C., Lavy, J., Allen, J., Blundell, D., Oscarsson, J., Emanuelsson, G., Perotti, M., Kenny, R. and Cunningham, G. (2000) The Air Assisted Direct Injection ELEVATE Automotive Engine Combustion System. SAE 2000-01-1899.

7 Lavy, J., Angelberger, C., Guibert, P. and Mokhtari, S. (2001) Towards a Better Understanding of Controlled AutoIgnition $\left(\mathrm{CAI}^{\mathrm{TM}}\right)$ Combustion Process from 2-Stroke Engine Results Analyses. SAE/SETC 2001-01-1859/4276.

8 Lavy, J., Dabadie, J.C., Angelberger, C., Willand, J., Juretzka A., Schaflein, J., Ma ,T., Lendresse, Y., Satre, A., Schulz, C., Kramer, H., Zhao, H. and Damiano, L. (2000) Innovative Ultra-low NOx Controlled Auto-Ignition Combustion Process for Gasoline Engines: the 4-SPACE Project. SAE 2000-01-1837.
9 Duret, P. and Lavy, J. (2000) Gasoline Controlled AutoIgnition $\left(\mathrm{CAI}^{\mathrm{TM}}\right)$ : potential and prospects for future automotive application. IMechE Conference, 21st Century Emissions Technologies, London.

10 Lavy, J., Dabadie, J.C., Duret, P., Angelberger, C., Le Coz J.F. and Cherel, J. (2001) Controlled Auto-Ignition (CAI): a New Highly Efficient and Near Zero NOx Emissions Combustion Processes for Gasoline Engine, Application. IFP International Congress, November 26-27, Éditions Technip

11 Duret, P. and Lavy, J. (1996) Process for Controlling SelfIgnition in a 4-Stroke Engine. US Patent 6082342.

12 Li, J., Zhao, H., Ladommatos, N and, Ma, T. (2001) Research and Development of Controlled Auto-Ignition (CAI) Combustion in a 4-Stroke Multi-cylinder Gasoline Engine. SAE Paper 01FL-393, Detroit.

13 Allen, J. et al. (2001) Advanced Combustion Using a Lotus Active Valve Train. Internal Exhaust Gas Recirculation Promoted Auto Ignition, IFP International Congress.

14 Doreau, J. (2001) Contribution of New Generation Variable Valve trains and Engine Management Systems for the Control of New Combustion Processes, IFP International Congress, Nov 26-27. D.E. Foster. An Investigation into the Effect of Fuel Composition on HCCI Combustion Characteristics. SAE 2002-01-2830.

15 Steiger, W. (2001) Volkswagen Strategy to High Efficient Powertrains. 22nd International Vienna Motor Symposium.

16 Montagne, X. and Duret, P. (2002) What Will Be the Future Combustion and Fuel-related Technology Challenges? IFP International Congress, Éditions Technip.

17 Olsson, J.O., Tunestal, P., Haraldsson, G. and Johansson, B.A (2001) Turbo Charged Dual Fuel HCCI Engine. SAE 200101-1896.

18 Duret P. Gasoline (2002) CAI and Diesel HCCI: the Way towards Zero Emission with Major Engine and Fuel Technology Challenges - SETC Kyoto October 2002. JSAE 20024280 \& SAE 2002-32-1787.

19 Jeuland N. and Montagne X. (2003) Engine and fuel related issues of gasoline CAI (Controlled Auto-Ignition) combustion. JSAE 2003-03-49, SAE 2003-01-1856., Society of Automotive Engineers of Japan congress, Yokohama, 19-22 May, Proceedings.

21 Jeuland N. and Montagne X. (2003) New approach to characterize the engine/fuel couple in CAITM combustion mode. Impact of fuels. Direkteinspritzung im Ottomotor IV. 5 Internationale Tagung, Essen, 1-2 July, Proceedings, 249-272.

Final manuscript received in December 2004 or distributed for profit or commercial advantage and that copies bear this notice and the full citation on the first page. Copyrights for components of this work owned by others than IFP must be honored. Abstracting with credit is permitted. To copy otherwise, to republish, to post on servers, or to redistribute to lists, requires prior specific permission and/or a fee. Request permission from Documentation, Institut français du pétrole, fax. +33147527078 , or revueogst@ifp.fr. 